\section{Handwarmers Benefit Young Citrus Trees during Freezes}

\author{
Lawrence R. Parsons and T. Adair Wheaton \\ Citrus Research and Education Center, University of Florida, Institute of Food \\ and Agricultural Sciences, 700 Experiment Station Road, Lake Alfred, \\ FL 33850
}

\section{George Yelenosky}

U.S. Department of Agriculture, U.S. Horticultural Research Laboratory, 2120 Camden Road, Orlando, FL 32803

Additional index words. Citrus sinensis, frost protection, tree wraps

\begin{abstract}
Handwarmers placed inside conventional insulating tree wraps increased trunk temperatures and improved tree survival under freeze conditions. Handwarmers generate heat by oxidation of $\mathrm{Fe}$ powder. In freeze-chamber tests with air temperature as low as $-7.1 \mathrm{C}$ for 4 hours, wraps plus handwarmers kept trunk temperatures above freezing. Handwarmers increased minimum temperatures by $7 \mathrm{C}$ during a one-night freeze. Benefit of the handwarmer decreased the second night of a simulated two-night freeze but still increased minimum temperature by $1.3 \mathrm{C}$. Tree survival was significantly improved by handwarmers in the freeze-chamber tests. In a field test during a mild freeze, handwarmers increased the minimum temperature by $3.5 \mathrm{C}$ the first night but provided no benefit the second night.
\end{abstract}

Insulating wraps have been used for decades to provide frost protection to trunks of young fruit trees (Jackson et al., 1983; Rose and Yelenosky, 1978). Most wraps do not generate heat but merely slow the rate of treetrunk cooling during a freeze. However, one wrap uses water-filled pouches between the tree trunk and insulating Styrofoam. When the temperature drops below freezing, water in the pouches freezes and releases the latent heat of fusion, which slows the temperature-drop rate of the tree trunk (Yelenosky and Reese, 1979).

Our study was designed to determine if handwarmers could be used as a heat source to improve insulating wrap effectiveness. Handwarmers, frequently used as a heat source for spectators during winter athletic events, contain $\mathrm{Fe}$ and charcoal powder stored in the absence of $\mathrm{O}_{2}$. When removed from their sealed wrapping and exposed to air, the Fe powder oxidizes and releases heat. Our objective was to evaluate the effectiveness of adding handwarmers to insulating wraps to provide cold protection to young citrus trees.

\section{Materials and Methods}

Handwarmers (Mycoal Warmers Co., Concord, Calif.) were evaluated in three tests. Two tests were conducted in freeze chambers at the U.S. Dept. of Agriculture, Horticultural Research Laboratory, Orlando, Fla. The third test

Received for publication 8 Apr. 1994. Accepted for publication 8 Sept. 1994. Florida Agricultural Expt. Station Journal Series no. R-03759. The cost of publishing this paper was defrayed in part by the payment of page charges. Under postal regulations, this paper therefore must be hereby marked advertisement solely to indicate this fact. used young citrus trees growing in a field plot at the Citrus Research and Education Center, Univ. of Florida, Lake Alfred. Each test included three treatments: 1 ) a control tree with no wrap, 2) a tree with a conventional tree wrap and no handwarmer, and 3) a tree with a conventional tree wrap plus a handwarmer (Table 1).

Handwarmer effectiveness was determined by monitoring the trunk temperature during the freeze events and evaluating tree survival 6 weeks after the freeze. A copper constantan thermocouple (TC) was taped to the trunk (Fig. 1), and temperature was recorded by a data logger at 10 -min intervals. The TC was $\approx 2$ $\mathrm{cm}$ above the upper edge of the handwarmer. Each experiment included four replications of single-tree plots in a randomized block design.

\section{Results and Discussion}

The sealed flexible package with a handwarmer was $9 \times 12 \mathrm{~cm}$ and $\approx 0.5 \mathrm{~cm}$ thick; it weighed $55 \mathrm{~g}$ and contained $16 \% \mathrm{Fe}$ and

${ }^{\mathrm{z}}$ Manufactured by Adaco Co., Clermont, Fla.

yManufactured by Frostproof Growers Supply, Frostproof, Fla. xInstalled.
$84 \%$ charcoal powder. The sealed envelope was removed before use, and the contents of the package was mixed by agitation for several seconds. Quantitative heat release data are not available, but packets became warm to touch within a few minutes after mixing and remained warm to touch for several hours. In preliminary freeze trials, a TC was placed directly under a handwarmer inside a wrap. When the temperature was lowered to $-7 \mathrm{C}$, the handwarmer raised trunk temperature by $>17 \mathrm{C}$ at $11 \mathrm{~h}$ after insertion inside the wrap.

Freeze chamber experiments. Test 1 was a simulated one-night freeze. Potted trees were moved from the greenhouse to the freeze chamber at $25 \mathrm{C}$. TCs were attached, handwarmers were installed, and wraps were placed on the trunks. The chamber temperature was lowered rapidly to $5 \mathrm{C}$, then reduced at $1.5 \mathrm{C}$ per hour to $-7.1 \mathrm{C}$, held there for $4 \mathrm{~h}$, and then increased at $1.5 \mathrm{C}$ per hour to $5 \mathrm{C}$. Trees were returned to the greenhouse for freeze damage observations.

Test 2 used a new set of potted trees and simulated a two-night freeze. The temperature-time profile for the first freeze night was identical to Test 1 . Then, the chamber was set at $20 \mathrm{C}$ until the same freeze program was restarted $24 \mathrm{~h}$ after the beginning of the test. The temperature of the control trees (Fig. 2) remained within $1 \mathrm{C}$ of the air temperature, except at the start of the test.

Wraps plus handwarmers resulted in higher minimum temperatures in both freezechamber tests (Table 2). Wraps alone provided some benefit, and wraps plus handwarmers provided even higher minimum temperatures. As expected, results from test 1 and the first night of test 2 were similar. With the wrap plus handwarmer, trunk temperature on the first night remained above freezing during the $4 \mathrm{~h}$ when the control cooled to $-7.1 \mathrm{C}$. During the second night of Test 2, the handwarmer still provided some heat and elevated the minimum by $1.3 \mathrm{C}$.

The benefit of wraps and wraps plus handwarmers is apparent (Fig. 2). The fiberglass wraps used in this experiment provided some benefit without the handwarmers. Wraps provided little initial insulating value, as indicated by the similar decrease in trunk temperature from 5 to $-5 \mathrm{C}$ for the wrap and control trees. However, moisture freezing in the wrap and releasing the latent heat of fusion resulted in a small increase in temperature at about $-5 \mathrm{C}$

Table 1. Characteristics of trees and wraps used in handwarmer experiments.

\begin{tabular}{|c|c|c|}
\hline Characteristic & Freeze chamber & Field \\
\hline Variety & $\begin{array}{l}\text { Valencia orange } \\
\text { Citrus sinensis (L.) Osb. }\end{array}$ & $\begin{array}{l}\text { Hamlin orange } \\
\text { C. sinensis }\end{array}$ \\
\hline Rootstock & $\begin{array}{l}\text { Rough lemon } \\
\text { C. jambhiri Lush }\end{array}$ & $\begin{array}{l}\text { Carrizo citrange } \\
\text { C. sinensis } \times \text { Poncirus } \\
\text { trifoliata (L.) Raf. }\end{array}$ \\
\hline Age (years) & 1 & 2 \\
\hline Tree height (m) & $0.82-0.85$ & $1.0-1.3$ \\
\hline Trunk diameter $(\mathrm{cm})$ & $0.9-1.1$ & $3-3.5$ \\
\hline Wrap type & Foil-backed fiberglass ${ }^{\mathrm{z}}$ & Closed cell polyethylene ${ }^{y}$ \\
\hline Wrap diameter $(\mathrm{cm})^{\mathrm{x}}$ & 10 & 9.5 \\
\hline Wrap height $(\mathrm{cm})$ & 38 & 37 \\
\hline
\end{tabular}




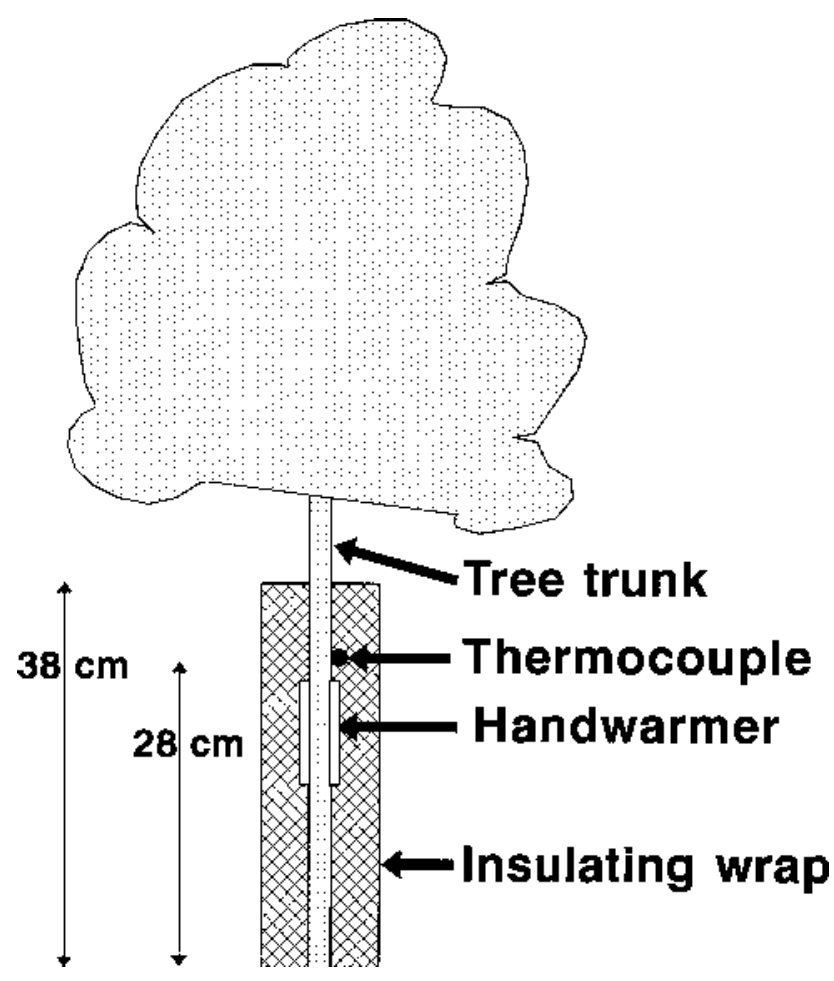

Fig. 1. Configuration of thermocouple (TC), wrap, and handwarmer during a freeze-chamber test using young citrus trees. One TC was taped to each trunk $28 \mathrm{~cm}$ above soil level. The handwarmer's protective cover was removed, and the handwarmer was agitated before being placed around the trunk. The insulating trunk wrap was installed snugly to minimize air leaks.

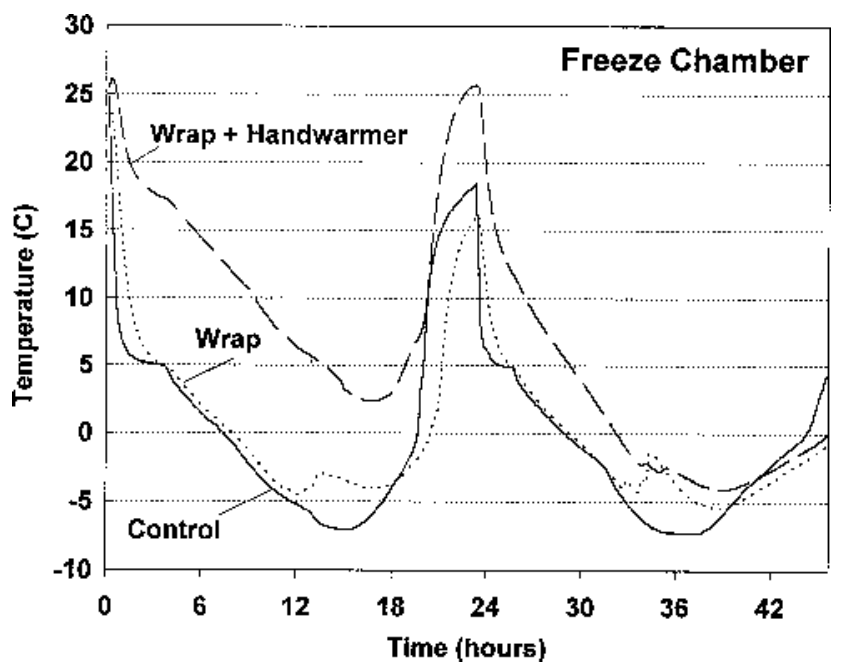

Fig. 2. Effect of wrap and wrap plus handwarmer on temperature profile during a simulated two-night freeze in a freeze chamber. Handwarmers were installed at $0000 \mathrm{HR}$. Temperature profiles during the one-night simulated freeze test were similar to profiles during the first night of the two-night test shown here. Temperatures shown are the mean of four replications.

Table 2. Minimum trunk temperature during three freeze tests and tree survival 6 weeks following tests.

\begin{tabular}{|c|c|c|c|c|c|c|c|}
\hline \multirow[b]{4}{*}{ Treatment } & \multicolumn{5}{|c|}{ Freeze chamber } & \multirow{2}{*}{\multicolumn{2}{|c|}{$\begin{array}{c}\text { Field test } \\
\text { Test } 3\end{array}$}} \\
\hline & & & & Test 2 & & & \\
\hline & \multicolumn{2}{|c|}{ Test 1} & \multicolumn{2}{|c|}{ Min temp } & \multirow[b]{2}{*}{$\begin{array}{c}\text { Survival } \\
(\%)\end{array}$} & \multicolumn{2}{|c|}{ Min temp } \\
\hline & $\begin{array}{l}\text { Min temp } \\
\left({ }^{\circ} \mathrm{C}\right)\end{array}$ & $\begin{array}{l}\text { Survival }^{2} \\
(\%)\end{array}$ & $\begin{array}{c}\text { 1st Night } \\
\left({ }^{\circ} \mathrm{C}\right)\end{array}$ & $\begin{array}{c}\text { 2nd Night } \\
\left({ }^{\circ} \mathrm{C}\right)\end{array}$ & & $\begin{array}{l}\text { 1st Night } \\
\left({ }^{\circ} \mathrm{C}\right)\end{array}$ & $\begin{array}{c}\text { 2nd Night } \\
\left({ }^{\circ} \mathrm{C}\right)\end{array}$ \\
\hline Control & $-7.1 \mathrm{a}^{\mathrm{y}}$ & $1 \mathrm{a}$ & $-7.1 \mathrm{a}$ & $-7.3 \mathrm{a}$ & $0 \mathrm{a}$ & $-1.3 \mathrm{a}$ & $0.2 \mathrm{a}$ \\
\hline Wrap & $-4.5 b$ & $25 \mathrm{~b}$ & $-4.6 b$ & $-5.4 \mathrm{~b}$ & $17 \mathrm{~b}$ & $-1.0 \mathrm{a}$ & $1.1 \mathrm{~b}$ \\
\hline $\begin{array}{l}\text { Wrap + } \\
\text { handwarmer }\end{array}$ & $2.5 \mathrm{c}$ & $37 \mathrm{c}$ & $2.2 \mathrm{c}$ & $-4.1 \mathrm{c}$ & $29 \mathrm{c}$ & $2.5 \mathrm{~b}$ & $0.9 \mathrm{~b}$ \\
\hline
\end{tabular}

${ }^{\mathrm{z}}$ Average height of surviving plants 6 weeks after freeze as percentage of initial tree height. Temperature in Test 3 was not low enough to cause damage.

y Mean of four replications; mean separation within columns by Duncan's multiple range test at $P<0.05$. and a subsequent reduced rate of temperature decline. This pattern kept minimum temperatures of wrapped trees a few degrees above the unwrapped control. Rose and Yelenosky (1978) noted the benefits of water freezing in fiberglass wraps.

Wraps and wraps plus handwarmers improved tree survival in both freeze-chamber tests (Table 2). Control trees were almost killed in both tests. Wraps alone provided some protection, and adding handwarmers provided more protection. Survival was generally better for the one-night freeze than for the two-night freeze.

Field experiment. Test 3 was conducted during a mild freeze (24-26 Jan. 1992) in a conventional field planting of young citrus trees. The temperature of the unwrapped control tree trunk dropped slightly below freezing the first night and was near freezing the second night (Fig. 3). The wrap plus handwarmer increased the minimum temperature the first night by $3.5 \mathrm{C}$ compared to the control or the wrapped tree. However, during the second night, minimum temperatures were similar for the wrap and the handwarmer plus wrap treatment (Table 2). This freeze was not severe enough to cause damage to the citrus trees, so no freeze damage evaluation was possible.

The increase in trunk temperature following application of handwarmers at $2330 \mathrm{HR}$ on 24 Jan. is evident (Fig. 3). The temperature increase was not nearly as large as that in the freeze-chamber tests; however, the wrap used for the field study was selected for ease of inserting the handwarmer and differed from the wrap used in the freeze-chamber studies. The wrap used in the field was less effective than fiberglass in maintaining nighttime temperature in earlier studies (Davies and Jackson, 1985; Oswalt et al., 1988), fitted the trunk more loosely, and probably allowed more air leakage. Other possible explanations for differences between the freeze-chamber and field studies include differing climatic conditions (e.g., air temperature, wind speed, and radiation conditions). We expect that the best results with handwarmers would be when using wraps with better insulating characteristics and better fit to the tree trunk.

In freeze-chamber and field tests, handwarmers significantly improved trunk temperatures under freezing conditions. Handwarmers improved tree survival in freezechamber tests, and it would be expected that the handwarmers would reduce freeze damage in the field during moderate freezes. Although no treatment protected the entire tree, substantial commercial benefits are obtained by protecting the bud union and as much of the trunk as possible. The greatest benefit of handwarmers occurred during the first night of a freeze. Increased trunk temperatures from handwarmers were greater than temperature increases previously reported for Styrofoam wraps with water-filled pouches (Yelenosky and Reese, 1979). The Styrofoam wraps are well-suited for large commercial plantings. Handwarmers can be used with less expensive wraps and could be beneficial in small plantings of citrus or other high-value crops. 


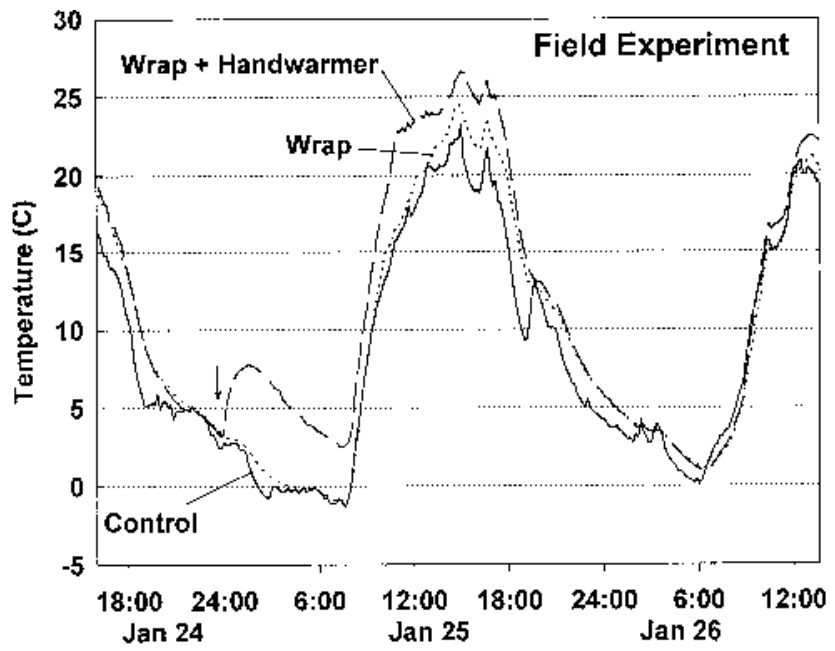

Time (hours)

\section{Literature Cited}

Davies, F.S. and L.K. Jackson. 1985. Methods of cold protection for young citrus trees. Univ. of Fla., Inst. of Food and Agricultural Sciences, Fruit Crops Fact Sheet FC 75, Gainesville.

Jackson, L.K., D.W. Buchanan, and L.W. Rippetoe. 1983. Comparisons of wraps and banks for citrus cold protection. Proc. Fla. State Hort. Soc. 96:29-31.

Oswalt, W.C., W.J. Wiltbank, and F.S. Davies. 1988. Tree wraps, trunk temperatures, and growth of young citrus trees. Proc. Fla. State Hort. Soc. 101:48-53.

Rose, A.J. and G. Yelenosky. 1978. Citrus trunk wrap evaluations. Proc. Fla. State Hort. Soc. 91:14-18.

Yelenosky, G. and S. Reese. 1979. Self-heating tree wraps in freeze protection. Proc. Fla. State Hort. Soc. 92:25-27.

Fig. 3. Effect of wrap and wrap plus handwarmer on temperature profiles (mean of four replications) during a mild freeze in the field. Handwarmers were installed on 24 Jan. at $2330 \mathrm{HR}$ as indicated by the arrow. 